\title{
Generation Y Challenges in Becoming Innovative Leaders at Organization in the 21st Century
}

\author{
Zahara Tussoleha Rony
}

\begin{abstract}
This paper aims to analyze and describe the dominant traits that are typical Gen-Y and innovative leadership models of the 21st century and to develop applicative recommendations on innovative leadership approaches to the Gen-Y. Gen-Y is increasingly inevitable and has taken a $50 \%$ portion in several large companies in Indonesia. This description explains the characteristics of Gen-Y and innovative leadership models. Data were obtained from secondary resource reviews, reputable journals, documents and company records that have relevance to the topic of this paper as well as from the results of interviews and observations on some companies. Gen-Y is the generation of innovating, open-mind. They are expected to be effective leaders in the 21st century. Innovative leadership becomes one of the effective leadership to be understood and implemented by Gen-Y in leading the organization in the 21st century
\end{abstract}

\section{Index Terms: Gen-Y, Innovative Leader, Organization.}

\section{INTRODUCTION}

Generation Y, the generation born after 1980 and has been widely discussed, the point they are a new generation with a different character from previous generations. There is at least three differentiation of the context of Generation Y, they are born of (1) relatively more stable economic conditions, (2) a more stable political situation (3) the dynamics of technological development is much more sophisticated. The entry of the younger generation in the workforce in an organization is something that cannot be avoided. Currently, young generation dominates the world of work. They are Generation Y or often called Gen-Y. Many of the Gen-Y mentioned by experts include NetGen, Google Generation, Digital Natives, Millennial (Balda \& Mora, 2011), (Cekada, 2012). (Cahill \& Sedrak, 2012) classify Gen-Y as a generation born between 1982 and 2000.

The presence of Gen-Y appears to be directly influential in the work environment and changes in organizational management, so a strategy that is appropriate to Gen-Y's behaviour, values and work ethics (Zopiatis, Krambia-Kapardis, \& Varnavas, 2012); (Anantatmula \& Shrivastav, 2012); (Luscombe, Lewis, \& Biggs, 2013). (Meister, 2012) claims that Generation Y will be roughly $50 \%$ of the USA workforce 2020 and $75 \%$ of the global workforce by 2030. The presence of this generation

Revised Manuscript Received on September 22, 2019.

Zahara Tussoleha Rony, University of Bhayangkara Jakarta Raya, Bekasi City, Indonesia. encourages the need for a study of leadership approaches which appropriate for both the leadership that they desire and prepare. Characteristics of Gen-Y according to (Kirana, Fee, Johari, \& Ain, 2015) is the new generation of workforce and it is a challenge to employers in terms of new working behaviour and attitudes, and the approach to retain them. Gen Y have their own set of values, own expectations and perceptions of authority and the ideal work environment.

In Indonesia 2015, Gen-Y or the Millennial Generation amounted to about 137.9 million people, according to Central Statistics Agency (BPS, 2016) and Generation Y taking over $75 \%$ of the workforce (Jalal, 2012) Companies in Indonesia have Gen-Y employees including, Kompas Gramedia 60,1\%, DBS 77\%, Zalora 80\% (JAPINDO, 2019) Among them will be a leader and driving force of the development of Indonesia in the 2020-2030 phase of the demographic. Therefore, the organization needs to do a lot of investment in nurturing and developing their employees in order to build superior employees to drive innovation (Oster, n.d.), wherein the end the Gen-Y employees will become leaders of the future.

Entering the 21st century, organizations are faced with a variety of business challenges that require an organization to build new capabilities. Challenges in disruptive era become relevant issues to organizational change that must be managed integrally is no longer partial. Companies in the era of globalization involve two dimensions that interact between human and technology. Humans perform organizational, while technology affects organizational systems that impact on changes in job design, work methods and organizational design.

Rapid technologies changes, make organization and its members more effective. In other words, the organization must create activities sustainable accounting in the structure, procedures and human aspects integrated within the system in place systematic work. Therefore it is necessary to prepare leaders who can accommodate issues related to the context of the change through awareness instructional leaders to fulfil their managerial competencies.

The presence of the Gen-Y and the challenges in unpredictable organizations it takes the right leadership in leading the organization, Because of that, the role of Gen-Y to become a future leader is crucial for the future development of the company(Eren, 2012).Various types of

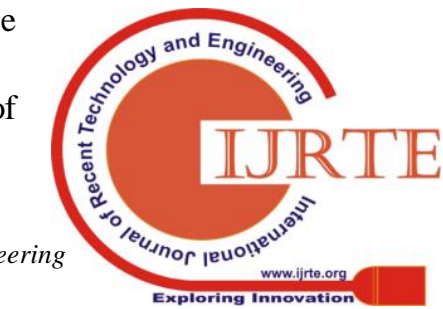




\section{Generation Y Challenges in Becoming Innovative Leaders at Organization in the 21st Century}

leadership include innovative leadership which is one type of leadership that can be implemented with conditions and situations in the 21 st century. Therefore, to provide a clearer picture of an effective leadership model for Gen-Y necessary analysis and a detailed description and applicative related to the suitability of the characteristics of Gen-Y and innovative leadership

\section{THEORETICAL STUDIES}

Generation $\mathrm{Y}$ is defined in general are all people born between 1982 and 2000 (Howe, Strauss, Shaw, \& Fairhurst, 2000). Millennial generation grew in the digital age. Gen-Y is a smart generation in terms of technology so that Generation $\mathrm{Y}$ is easy to communicate with other people and access information quickly and instantly (Bassett, 2008) and (Erickson, 2008). The increasing accessibility of e-mail and cell phones, social media they also spend time working anywhere, regardless of where they are (Bolton et al., 2013). Millennials believe that they can work more efficiently. More specifically, they can eliminate what they consider the time wasted, non-essential, face-to-face interactions occurring in a more typical office setting (Erickson, 2008).

The Generations that grow in a rapidly changing environment, not only expect change but want it. They need opportunities to grow and expand within and outside the organization. When the needs are not met, they will not hesitate to find a suitable place to develop themselves. This generation has high hopes and beliefs about the future. They are multitasking, love dynamic life and move quickly. It can be said that the technological fascination begins with this generation. Gen-Y is the latest generation of workers entering the workforce today (Kristensen, 2008).

Generation Y describes a group of people who value teamwork and comfortable in groups. They mentality is slightly different from other generations (Cole, Lucas, \& Smith, 2002). Gen-Y is a collaborative Google generation. The effect of the presence of technologists makes Gen-Y tend to be in groups. Duties and activities are always done together and in groups rather than alone. This is beneficial for those who are less adaptive and tend to dominate will learn to work together well.

Generation Y also anticipates job change. (Cruz, 2007), it illustrates that the millennial generation has shown a willingness to change organizations when they see new opportunities that offer a greater chance level than what they are achieving right now. Compared to the baby boomers their parents, the millennium generation emphasizes more on family relationships than on the job and, because of this they have a working interest from home (Concours, 2007). Ethics Resource Center stated that Generation $Y$ has the characteristics as presented in the table below.

The survey shows that $51 \%$ of Gen-Y needs a leader figure that can be coach/mentor for the development of ability and career. Leaders are expected to understand them well, ensuring they are on the right track in achieving the desired outcomes, therefore awareness of the curiosity of mastering managerial competencies tailored to the Gen-Y is an important factor. (Rony, 2017)
The existence of Gen-Y, leaders must pay attention to the style and behavior of leadership within the organization to achieve organizational success (Jex \& Britt, 2008). Leadership style and behavior refers to the activities of leaders, including characteristic and effectiveness approaches. (Boyce, Zaccaro, \& Zazanis, 2010) says that a person's traits tend to help understand the style of leadership. (Jex \& Britt, 2008) say leadership behavior is the behavior of superiors in interacting with subordinates, therefore it is important for a leader to pay attention to his style and behavior in the lead.

\section{Table Characteristics of Generation Y at Work} Generation $\mathbf{Y}$

\begin{tabular}{|c|c|}
\hline $\begin{array}{l}\text { Positive } \\
\text { Characteristic } \\
\text { s }\end{array}$ & $\begin{array}{l}\text { - Intelligent Technology } \\
\text { - Accustomed and Appreciate diversity }\end{array}$ \\
\hline $\begin{array}{l}\text { Negative } \\
\text { Characteristic } \\
\mathrm{s}\end{array}$ & $\begin{array}{l}\text { - Less foundation of basic literacy } \\
\text { - Have a short attention period }\end{array}$ \\
\hline $\begin{array}{l}\text { The behavior } \\
\text { in the } \\
\text { workplace }\end{array}$ & $\begin{array}{l}\text { - Superior in integrating technology in } \\
\text { the workplace } \\
\text { - Want fast feedback and recognition } \\
\text { - Expect to have a Leaders who take the } \\
\text { time to discuss performance }\end{array}$ \\
\hline
\end{tabular}

Source: Ethics Resource Center (2013)(Raytehon, 2013)

It is more crucial when Gen-Y must be ready to lead. When viewed from Howe and Strauss's theory by 2018, Gen-Y constellation is 36 years old and they already have a leadership position. In accordance with the challenges in the 21 st century that innovative leaders are urgently needed at the moment. At this point, Gen-Y is no longer merely followers, they are already leaders. When Gen-Y wishes to be led by an approach that suits their character, they are also genuinely preparing for their competence.

Leadership problems have existed since the beginning of human history since humans realized the importance of group life to achieve common goals. They need and depend even they need some people who have more advantages than others. Although the change is very fast, even the generation has changed leaders is necessary for accordance with the conditions and the present situation. Today's leaders are able to transform their thinking patterns into adaptive leaders that change easily according to the demands of the times and can treat multigenerational employees according to their character.

(Samad \& Abdullah, 2012) argue that no single leadership theory is appropriate for all situations. But a leader needs to find, understand and implement the most appropriate approach of the times and especially to each of the organizational cultures of the company. For Gen-Y in the era of disruption, an innovative leadership approach can play many roles in facilitating innovation within the organization.

Today's leaders are able to inspire and support their teams to achieve organizational goals (DuBrin, 2011). Even (Bass \& Riggio, 2006) sharpens that leadership is the ability to lead a group toward achievement of goals and ultimately can achieve the vision and mission of the organization 
(Chen, 2007); (Samad \& Abdullah, 2012); (Sattayaraksa \& Boon-Itt, 2012). Other empirical studies consistently postulate that leadership is one of the most important factors for organizational success (Lebrasseur, Whissell, \& Ojha, 2002); (Samad \& Abdullah, 2012); (Seltzer \& Bass, 1990).

Leaders in organizations are required to innovate to create value greater than costs incurred (impacted vision). Today's leaders must be able to create ecosystems in achieving business performance and social performance simultaneously (Rony, 2015). Leaders who are able to encourage people in the organization to achieve a legacy. Leaders are one of the keys to the success of keeping the company fluttering. The more complex the problem of the company, the more competence required to become a leader today is that the leader must be able to sort and choose the competencies to be practiced in accordance with the internal and external environmental conditions.

Some other competencies needed are required accordingly (Rony, 2015) is Enablement, which is the process of forming everyone to become more empowered, capable and independent. They run the process learn and unlearn, Enablement not just soft skills and hard skills. But also inner skills, the ability to know yourself, self-conscious, so aware of the task of life, Autonomy, involving flexibility to the time, type of work, work patterns and work teams. In Autonomy, employees are given space to conduct trial and error in the charge. Learning to run a failure, Autonomy asks the organization's willingness to beat efficiency for a breakthrough. Autonomy is absolutely necessary to trust (trust), the leader will ensure the honesty and consistency between words and actions (integrity), best intentions for the common interest (benevolence), ability to run what is promised (ability). Community, the process of facilitating relationships, not just a working relationship. Between one individual and another, between one group and another.

In other words, leaders must be able to master an integrated strategy ranging from the corporate level, responsiveness to sensitivity in generating solutions to changes that exist outside the organization and impact on business strategy, creating engagement to customers both to internal and external customers. In addition to having the reliability in the field of technical specificity in the strategy at the operational or functional level, so that responsive to the needs of scientific improvement, another important thing is the strategy of personnel, the approach is built directly or indirectly by leaders are flexible and dynamic in addressing the generation and organization.

Corporate leaders need to understand how to interact, communicate and treat them appropriately. It is expected to create a sense of attachment to the company. With the emergence of a sense of ownership can automatically enhance team collaboration and create more effective multigenerational teams. In other words, learning to understand the difference in generation goes hand in hand with understanding the different styles of leadership that fit certain types of people, so they are more resilient and responsible for their work.

More detailed characters of innovative leaders according to (Zenger \& Folkman, 2014) (De Jong \& Den Hartog, 2007) and (Brown, 2008) as follows:
1. Model examples of innovative behavior. Leaders give examples of how to look for opportunities, take ideas and be role models in the application of an innovative idea.

2. Providing vision direction. The leader clearly communicates the vision associated with the employee's role in innovation and the kind of innovation that is expected.

3. Giving intellectual stimulation. Invite subordinates to provide ideas and invite them to evaluate how the work that now applies to see the possibility to be repaired.

4. Inviting employees to share knowledge. Leaders demonstrate open and transparent communication, inviting employees to communicate in an informal environment in the workplace.

5. Giving feedback is honest, forthright, and candid, although sometimes very sharp and critical.

6. Inspiring and motivate through action (inspire) Innovative leaders will be inspired and moved by the imagination of the realization of that innovation. Promising innovation and emotionally engaging the heart to be able to move himself and his people to work harder so that it can immediately realize the idea.

7. Giving consultation. Discuss with your employees throughout every change and, to accommodate ideas and suggestions of employees in decision making also something related to innovation.

8. Delegating work. Dreamer and gives considerable autonomy to employees so that they can independently take care of the job.

9. Supporting innovation, paying attention, supporting innovative ideas is patient with ideas, looking for ways to solve problems.

10. Having good listening skills.

11. Giving positive feedback (feedback on ideas and early stages of implementation of innovation, and ask consumer opinion to know their reaction to innovation activities.

12. Recognition. Leaders show their appreciation for the innovative performance. By providing this recognition, employee fined something to proud of himself.

13. Providing rewards and facilities to support innovative activities, whether in the form of money, facilities or goods.

14. Providing the assignment. The leader gives a challenging task and opportunity (time, etc.) for employees to realize his commitment to duty.

15. Creating a climate of mutual trust (mutual trust). Innovation is often associated with a variety of risks, including regulations that do not support, boundary infrastructure.

16. Having a commitment to organization and customer. They are keen to see customer oriented point of view and connect with customers and have a concern about customer's needs and wants and engage customers in innovating. 


\section{Generation Y Challenges in Becoming Innovative Leaders at Organization in the 21st Century}

17. Creating a culture to hear ideas, accept ideas and appreciate all ideas from all sides. Able to build equality at all levels of the organization.

Setting the reach very well so as to be able to formulate the final goal into measurable targets. Establish an appropriate indicator or parameter for each process of the activity.

\section{RESEARCH METHOD}

The research design is narrative, emphasized the information in the form of facts, related data characteristics of Gen-Y employees and the lead character innovative compiled from research into HR management experience and project leader of Human Resources in company public and private sector, corporate leaders as well as the collection of documents.

This research combines the collective normative and empirical studies. Analyze normative character concept employee examines Gen-Y and innovative leadership of the various theories whereas empirical analyze the extent of the character's reality Gen-Y and implementation of innovative leadership gained from the experience of corporate leaders. Details of the research steps are: identifying Gen-Y, collecting documents and attending seminar base on this studies, focus group discussions with some practitioners, interviewing $10 \mathrm{Gen}-\mathrm{Y}$ leaders in large private firms with employees over 500 employees at random sampling. Details of the research steps are: identifying the phenomenon of the Gen-Y, collecting documents and attending seminars, related to the theme of this research, conducting interviews with 10 leaders of Gen-Y in large private companies that have employees over 500 employees. The results of the interviews are made with a matrix by creating tables, dividing and data entry into segments and naming segments with coding and validating the findings by conducting focus group discussions with several practitioners..

\section{RESULTS AND DISCUSSION}

Millennial Generation grows in the digital era always using instant communication technologies such as email, SMS, instant messaging also social media like facebook, twitter, and Instagram. Sophistication job technology makes Gen-Y creates a working atmosphere with the atmosphere with continuous improvement and develops a culture of innovation. Creates the culture needed work environment is dynamic and the opportunity was excluded ideas and creativity, completing a challenge that can express the maximum presence of technology for Gen-Y to help them get the information quickly and accurately so as to encourage them to be an innovative leader in doing continues improvement. They play a role in changing the ways and processes of work and working methods to be effective and efficient. In addition to this important activity, they apply the evaluation into a mandatory activity. One of the activities that they apply and move all the elements of the team to achieve the vision. They recognize these ways they get from the sharing and training of managerial competence. From the results of interviewing the Gen-Y leaders, they feel that technology makes it easier for them to change work methods and processes and work methods to be effective and efficient. Besides that, they are easy to carry out monitoring and evaluation. According to the leader of the Gen-Y, technology change is the beginning of a change in new civilizations and can increase their intellectuals.

Gen-Y sees change as a challenge. They have ambitions and are never satisfied with "comfortable" conditions. They often voiced change. For them, staying or complacent with the current conditions is riskier than trying something new. They continue to look for opportunities to raise their organization. They are able to inspire many people to be successful by relying on innovation. They also anticipate and act proactively before these challenges hit bravely often they act outside the rules because it is required to find creative new ways to satisfy the customer. From their actions, they approach innovative leaders that are thinking ahead and alert to changes in regulation, customer habits, trends, and the business environment. That innovative leader challenged coexist fat is dynamic, creative and also demonstrate a proactive attitude and has a capacity in response to changes that bring innovation, renewal, and success for the organization of the majority of Gen-Y leaders, they often do trial and error both in making products and programs, not even a few of them suffer losses. Therefore, they are not afraid of failing Innovative leaders regard failure as part of the learning to achieve success. They tend to see the value and potential that organizations have rather than just looking at operational costs.

Gen-Y used to work in groups since they were in high school and college. They are trained to dialogue, argue, test logic and proficient presentation using various multimedia. When they enter and work, they are accustomed to a group work atmosphere that challenges logic and thinking in their workplace. Statement from several theorists is also experienced by the leader of the Gen-Y and they realize that it becomes a useful provision to make them innovative leaders. The activity becomes provision profitable $\mathrm{m}$ hey generate new creativity and innovations. When they lead they can synergize well. The collaboration will be the key to success in innovation. When they find the lack of resources to achieve organizational goals, they seek partners to strengthen the team so that their goals are achieved. Even though they are happy to synergize, Gen-Y it is not easy to take things for granted without questioning why. They tend to always ask "why" in communicating. In communicating with Gen-Y, leaders must convey information clearly, transparently and candidly. Gen-Y wants to be given the opportunity to talk and ask questions about everything. Gen-Y thinks that everyone in the company is a team, Many Companies, among others, Bluescope, Trans 7, MNC, consider Gen-Y is a partner, a collaborator, so even with leaders/superiors they consider talking to colleagues/friends rather than with people who are the higher position. Usually, this is simply because they want to communicate freely, openly and clearly; not because they are impolite or impolite, in some companies like Citibank and Net TV they usually call the boss by name without having to use the Sir, mam or miss according to (Brown, 2008), that innovative leaders are able to build equality at all levels of the organization.

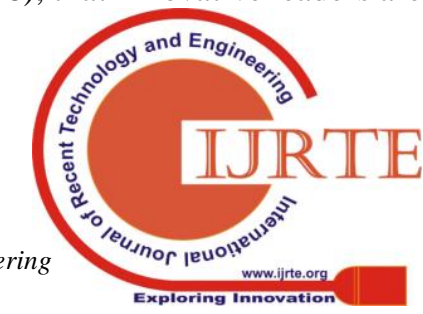


From the results of interviews with Gen-Y leaders, they stated that building a solid team is important. They are keen to build a solid team. The team was built from scratch or the old team rejuvenated, therefore they need a lot of time to observe and interact, communicate, discuss issues regularly to get the company's decisions appropriately. They are sometimes constrained to identify the passion of themselves and their groups. According to them Passion will make a leader of spirit and energized even in worse conditions though. Passion will drive them to achieve the dream. As followers, they need to be directed, as their leader must determine the direction to achieve the goal. They spend their time describing the vision and goals of the organization and the challenges it faces. The true leader can ensure the clarity of the organization's goals to all members of the organization (clarity of organizational). Innovative leaders lead with consistent, real, walkthrough behavior, and using non-arbitrary authority, not leaning on labels, money and but concentrates on improving, developing, also achieving more individual and organizational goals.

Gen-Y has a high self-esteem, but that does not mean they do not want to be better. They need direction, especially they can get information easily, but they still need direction, therefore when running a job they want to know management views or feedback from their boss on the work they do. Unfortunately, most of the leaders not getting used to provide feedback to their employees. Employees are considered "paranormal" who must know their own shortcomings and weaknesses. Employees are often left wondering "I am doing a good job or not?" When Gen-Y is always curious if their work is doing well and they want the feedback too. The employees of Gen-Y expect their bosses to be able, to provide clear guidelines and working standards, foster a group-oriented work culture and provide feedback as quickly as possible for self-improvement measures.

They require performance information as often as possible. This millennial group wants to learn, grow, and grow. Unlike baby boomers who are just waiting for the annual review. They want to get feedback (feedback) on a daily basis. Feedback is anticipated activities when they do work or solve the problem, there is always a way not maximally in solving the problem. They are often limited by the perspective that does not draw from yourself and the challenges faced. They want to be heard. Moreover, sometimes they know more and do more things that are more fitting for current conditions than given a lot of instructions. At that point, it takes good feedback.

Feedback through constructive help to sharpen, uphold and expand the vision of the leader. The experience and needs of Gen-Y will be feedback to make them realize that when they lead they are not necessarily able to act properly all the time because they do not have the right answers to all the problems. Constructive feedback helps a leader learn to do things right. A good leader will continue to look for feedback are able to provide better service for customer needs.

Feedback activities will cause the people they lead to understanding the mindset of their leaders and feel confident in them, thus helping them to come to their respective duties and functions in following their leader's logic, belief, and leadership. It will also build confidence in the team, so they all understand the problems and challenges that are and will be facing. In the feedback, skill becomes quite a tough job when they will become leaders. Most of the time they communicate through cyberspace, the skills they communicate using all the physical attributes, the tone of voice, are automatically reduced. They are accustomed to using short messages. Communication skills using full attributes including relying on gesture to be one of the tasks and skills that must be developed to be an effective innovative leader.

Generation $\mathrm{Y}$ has a need for them to be involved in the work and not just given orders alone, by being involved in the work they will contribute maximally to the work because with the achievement of the goal will give satisfaction and appreciation. Generation Y requires leaders who are able to provide good examples for them, they want an authentic/consistent leader between speech and action. Generation Y wants to be treated like a non-subordinate work partner. In addition, they want companies to have systems that can develop themselves, either through the process of ex-principal learning, mentoring and training or through one-on-one coaching systematic. Another system is a reward system for those rewards is not just a salary alone but a reward system that provides a signature experience, a system that involves justice for the company and employees.

In another word the mental readiness running political ethics within the company. In the face of rapid change requires the soul of competition. Gen-Y leaders have ambition, but when it has to compete in the work environment of high levels of conflict will arise an inconvenience, and therefore they should be ready with the situation. They suggested holding the golden principle role is to treat others as he wants to be treated so that the leader is able to raise the issue of innovative strategies and encourage everyone to participate to resolve those issues for the success of the organization.

Gen-Y will certainly lead to a major change in the world. The role is very important in influencing creativity and innovation. Exposure of a successful researcher innovate be realistic and achievable objectives (Hunter \& Cushenbery, 2011). Innovative encourage and control change. Change process transforms organizational elements into creative, effective, and productive. Despite many organizational requirements in getting the benefits. Leadership is the most important source of excellence. Gen-Y will be the leader of the organization, they will decide what happens within the organization and provide direction, vision, to achieve success. They will be the catalyst that creates, manages the environment and organizational culture and creates strategies that drive and sustain innovation, the effectiveness of success within organizations. Even former GM Human Capital of PT. Wijaya Karya Beton, Agung convey the best fit to face disruption era is innovative leadership. "Leader-based innovation is always pushing his team to create new innovations.

\section{CONCLUSION}

Most of the characteristics of Gen-Y and innovative leadership characters have 


\section{Generation Y Challenges in Becoming Innovative Leaders at Organization in the 21st Century}

similarities. Both are characterized by liking change, visionary and happy to innovate. From such a powerful equation, Gen-Y has the provision to be an innovative leader in the 21 st century. They understand the character of a leader to be desired, they are involved in the circumstances led and lead the transformation process itself, but things that should be prepared there was characteristic persistence in realizing changing implementation and skilled leadership competencies. Experiential learning and learning by doing is the activity of increasing the competence of Gen-Y to become successful innovative leaders. This innovative leadership styles that are applied within an organization will shortly result in many innovations. Innovation is ultimately largely determined by the ability of corporate leaders to motivate employees to actualize all their potential.

\section{REFERENCES}

1. Anantatmula, V. S., \& Shrivastav, B. (2012). Evolution of project teams for Generation Y workforce. International Journal of Managing Projects in Business. https://doi.org/10.1108/17538371211192874

2. Balda, J. B., \& Mora, F. (2011). ADAPTING LEADERSHIP THEORY AND PRACTICE FOR THE NETWORKED, M I L L E N N I A L G E N E R AT I O N, 5(3), 13-24. https://doi.org/10.1002/jls

3. Bass, B. M., \& Riggio, R. E. (2006). Transformational leadership (2nd ed.). Transformational Leadership (2nd Ed.) https://doi.org/10.1002/1521-3773(20010316)40:6<9823::AID-ANIE 9823>3.3.CO;2-C

4. Bassett, B. (2008). Working with generation Y. Office Pro, 68(2), 16-19.

5. Bolton, R. N., Parasuraman, A., Hoefnagels, A., Migchels, N., Kabadayi, S., Gruber, T., ... Solnet, D. (2013). Understanding Generation Y and their use of social media: a review and research agenda, 24(3), 245-267. https://doi.org/10.1108/09564231311326987

6. Boyce, L. A., Zaccaro, S. J., \& Zazanis, M. (2010). Propensity for self-development of leadership attributes : Understanding, predicting and supporting performance of leader self-development. The Leadership Quarterly, 21(1),

$159-178$ https://doi.org/10.1016/j.leaqua.2009.10.012

7. BPS. (2016). Tingkat Pengangguran Terbuka (TPT). Bps.

8. Brown, M. (2008). The Innovative Leader: How to Inspire your Team and Drive Creativity. Library Review. https://doi.org/10.1108/00242530810875258

9. Cahill, T. F., \& Sedrak, M. (2012). Leading a multigenerational workforce: strategies for attracting and retaining millennials. Frontiers of Health Services Management. https://doi.org/10.1097/01974520-201207000-00002

10. Cekada, T. L. (2012). Training a Multigenerational Workforce. Professional Safety.

11. Chen, M. H. (2007). Entrepreneurial leadership and new ventures: Creativity in entrepreneurial teams. Creativity and Innovation Management. https://doi.org/10.1111/j.1467-8691.2007.00439.x

12. Cole, G., Lucas, L., \& Smith, R. (2002). The debut of Generation Y in the American workforce. Journal of Business Administration Online.

13. Concours, B. S. G. (2007). Engaging Today's Young Employees. Results Research Project YE.

14. Cruz, C. S. (2007). Gen Y: How boomer babies are changing the workplace. Hawaii Business, 52(11), 38.

15. De Jong, J. P. J., \& Den Hartog, D. N. (2007). How leaders influence employees' innovative behaviour. European Journal of Innovation Management. https://doi.org/10.1097/SPV.0b013e3182a331a9

16. DuBrin, A. J. (2011). Impression management in the workplace: Research, theory, and practice. Impression Management in the Workplace: Research, Theory, and Practice. https://doi.org/10.4324/9780203865712

17. Eren, E. (2012). Innovative Leadership for the Twenty-First Century. Procedia Social and Behavioral Science, 41, 1-14 https://doi.org/10.1016/j.sbspro.2012.04.001

18. Erickson, T. (2008). Plugged in: The generation Y guide to thriving at work. Harvard Business Review Press.

19. Howe, N., Strauss, W., Shaw, S., \& Fairhurst, D. (2000). Millennials Rising: The Next Greatest Generation. Education + Training.

20. Hunter, S. T., \& Cushenbery, L. (2011). Leading for innovation: Direct and indirect influences. Advances in Developing Human Resources. https://doi.org/10.1177/1523422311424263

21. Jalal, M. O. (2012). Manajemen Mengenal Siapa Itu Generasi Y, 1-10. Retrieved https://manajemenppm.wordpress.com/2013/07/08/mengenal-siapa-itugenerasi-y/

22. JAPINDO, P. M. T. K. (2019). Perusahaan Besar Ini Didominasi Karyawan Millennial. S.M.L Journal, 2019(X), 1-7. Retrieved from http://xsmlfashion.com/tab/984/5-perusahaan-besar-ini-didominasi-kar yawan-millennial

23. Jex, S. M., \& Britt, T. W. (2008). Organizational Psychology: A Scientist-Practitioner Approach 2nd Edition. John Wiley \& Sons, Inc. https://doi.org/10.1016/j.jpainsymman.2010.06.024

24. Kirana, K., Fee, T., Johari, J., \& Ain, N. (2015). The Perception of Gen Y on Organizational Culture, Religiosity and Corruption in Malaysian Public Organizations. Procedia Economics and Finance, 31(15), 251-261. https://doi.org/10.1016/S2212-5671(15)01227-7

25. Kristensen, J. (2008). Recruiting and Retaining Generation Y. Msc. International Business Economics, Aalborg University.

26. Lebrasseur, R., Whissell, R., \& Ojha, A. (2002). Organisational Learning, Transformational Leadership and Implementation of Continuous Quality Improvement in Canadian Hospitals. Australian Journal of Management. https://doi.org/10.1177/031289620202700203

27. Luscombe, J., Lewis, I., \& Biggs, H. C. (2013). Essential elements for recruitment and retention: Generation Y. Education and Training. https://doi.org/10.1108/00400911311309323

28. Meister, J. (2012). The Future Of Work: Job Hopping Is the "New Normal" for Millennials

29. Oster, G. (n.d.). Emergent Innovation: A New Strategic Paradigm.

30. Raytehon. (2013). Generational Differences In Workplace Ethics. Ethics Resource Cente. Retrieved from www.ethics.org/nbes.

31. Rony, Z. T. (2015). KESIAPAN LULUSAN PERGURUAN TINGGI MENETAPKAN AWAL PEMILIHAN KARIER DENGAN MODEL COACHING. PARAMETER: Jurnal Pendidikan Universitas Negeri Jakarta, 26(1), 107-117.

32. Rony, Z. T. (2017). THE IMPACT OF COACHING AND MENTORING ACTIVITIES TOWARDS DECREASING CREATIVE IDEAS OF GEN Y EMPLOYEES IN MEDIA COMPANY. Journal, Indonesian Review, Educational, 4(1), 179-191.

33. Samad, S., \& Abdullah, Z. (2012). The influence of leadership styles on organizational performance of logistics companies. International Business Management. https://doi.org/10.3923/ibm.2012.374.383

34. Sattayaraksa, T., \& Boon-Itt, S. (2012). Leadership as a determinant of product innovation: A systematic review of the literature. In IEEE International Conference on Industrial Engineering and Engineering Management. https://doi.org/10.1109/IEEM.2012.6837825

35. Seltzer, J., \& Bass, B. M. (1990). Transformational Leadership: Beyond Initiation and Consideration. Journal of Management. https://doi.org/10.1177/014920639001600403

36. Zenger, J., \& Folkman, J. (2014). Research : 10 Traits of Innovative Leaders, 2014-2017.

37. Zopiatis, A., Krambia-Kapardis, M., \& Varnavas, A. (2012). Y-ers, X-ers and Boomers: Investigating the multigenerational (mis)perceptions in the hospitality workplace. Tourism and Hospitality Research. https://doi.org/10.1177/1467358412466668

\section{AUTHORS PROFILE}

Dr. ZaharaTussoleha Rony, M.M is a Human Capital Strategiest. Her experiences in the field Human Resources Management has been 18 years, she is an active Career Coach in various companies, and a permanent lecturer at Bhayangkara University, Jakarta as well as Chair of the Jakarta Red Cross Provincial organization period 2017-2022. Her experience on the process of searching a truth and moto does not need to wait great to do something is her motivation to do writing and conducting research. She had published Two books : Who Should Leave, Who Should Stay (A Strategy of Preventing Gen Y Employees Turnover) and Siap fokus, Siap Menulis Skripsi, .Tesis: Disertation: Jurus Mudah Gunakan Metode Kualitatif. The author can be contacted via e-mail at: zararony@gmail.com 